\title{
Environmental enrichment for rabbits reared in cages reduces abnormal behaviors and inactivity
}

\author{
Enriquecimento ambiental para coelhos criados em gaiolas \\ reduz comportamentos anormais e inatividade
}

\author{
Maria Camila Ceballos ${ }^{\mathrm{I}, \text { II }}$ Karen Camille Rocha Góis ${ }^{\mathrm{II}}$ II \\ Monique Valéria de Lima Carvalhal, II Franciely de Oliveira Costa ${ }^{\mathrm{I}}$, II \\ Mateus Paranhos da Costa ${ }^{\text {II, III }}$
}

ABSTRACT

The aim of the study was to evaluate the effect of environmental enrichment with forage (as extra food) on the time spent in inactivity and expressing self-cleaning and abnormal behaviors by rabbits kept in cages. The study was conducted in 17 New Zealand multiparous females at the rabbit facilities in Faculdade de Ciências Agrárias e Veterinárias, Universidade Estadual Paulista (FCAV-UNESP). Three species of forages were offered simultaneously as environmental enrichment, sugar cane (Saccharum officinarum sp.), mulberry (Morus alba) and ramie (Boehmeria nivea). Behavioral observations were carried out before and after enriching the environment; this was done in four observational periods for each condition, two in the morning (from 06h00min to 09h30min) and two in the afternoon (from 15h00min to 18h00min). Rabbits'behaviors where recorded by direct observation with instantaneous records (with $2 \mathrm{~min}$ sampling interval) and using animal focal sampling. The time spent in six behavioral categories ( $I=$ inactivity, $S C=$ self-cleaning, $A B$ = abnormal behaviors, $C I=$ concentrate and $F I=$ forage ingestion, and $O A=$ other activities) were recorded before and after adding the environmental enrichment. Data were compared using Wilcoxon test. Animals used the environmental enrichment in both periods of the day, and it reduced significantly $(P<0.05)$ the time spent in $A B$ and $S C$ in the morning and I in the afternoon. We concluded that offering forage as environmental enrichment improves the welfare of rabbits kept in cages, as shown by the reduction in the time spent by them showing self-cleaning, abnormal and inactive behaviors.

Key words: Oryctolagus cunniculus, feed enrichment, animal welfare, behavioral needs.

RESUMO

O objetivo do estudo foi avaliar o efeito do enriquecimento ambiental no tempo despendido na expressão de comportamentos anormais, autolimpeza e inatividade por coelhas mantidas em gaiolas convencionais. $O$ estudo foi realizado no setor de cunicultura da Faculdade de Ciências Agrárias e Veterinárias, Universidade Estadual Paulista (FCAV-UNESP), campus Jaboticabal-SP. Dezessete fêmeas multíparas da raça Nova Zelândia foram observadas antes e após o oferecimento do enriquecimento. Três espécies de forrageiras foram utilizadas como enriquecimento ambiental: cana de açúcar (Saccharum officinarum sp.), amora (Morus alba) e rami (Boehmeria nivea). As observações foram realizadas de forma direta com registro instantâneo (com intervalos amostrais de 2 minutos) e amostragem por animal focal, sendo conduzidas em duas etapas (antes e depois da introdução do enriquecimento), com quatro periodos de observação para cada etapa, dois pela manhã (06h00min às 09h30min) e dois pela tarde (15h00min às 18h00min). As seguintes categorias comportamentais foram observadas: inatividade (I), autolimpeza (AL), comportamentos anormais (CA), consumo de ração (CR), consumo de forragem $(C F)$ e outras atividades (OA), sendo registrado o tempo médio despendido pelos animais em cada uma dessas categorias, antes e após a oferta do enriquecimento ambiental. O teste de Wilcoxon foi usado para realizar as comparações do tempo médio antes e após o enriquecimento. Os animais utilizaram o enriquecimento ambiental em ambos os períodos do dia, sendo que a oferta de forragem reduziu significativamente $(P<0,05)$ o tempo médio despendido de CA e AL no periodo da manhã e de I $(P<0,05)$ no periodo da tarde. Concluiu-se que o oferecimento de forragem como enriquecimento ambiental melhora o bem-estar decoelhos mantidos em gaiolas, como caracterizado pela redução do tempo despendido na expressão de comportamentos anormais, de autolimpeza e em inatividade.

Palavras-chave: Oryctolagus cunniculus, enriquecimento alimentar, bem-estar animal, necessidades comportamentais.

\footnotetext{
'Programa de Pós-graduação em Zootecnia, Faculdade de Ciências Agrárias e Veterinárias, Universidade Estadual Paulista (UNESP), Jaboticabal, SP, Brasil.

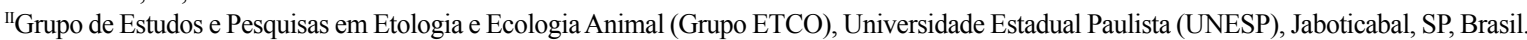

IIIDepartamento de Zootecnia, Faculdade de Ciências Agrárias e Veterinária (FCAV), Universidade Estadual Paulista (UNESP), Via de Acesso Prof. Paulo D. Castellane, km 5, 14884-900, Jaboticabal, SP, Brasil. E-mail: mpcosta@fcav.unesp.br. Corresponding author.
} 


\section{INTRODUCTION}

There is a growing interest amongst contemporary consumers to know about the production processes used in making the food they want to purchase, not only in respect to product quality, but also in terms of food safety and ethical issues, such as welfare of farm animals (OLIVEIRA et al., 2008). These concerns set new challenges to animal production, including the development of beneficial production strategies, such as developing and adopting good handling practices that promote the welfare of farm animals.

Animal welfare is defined by BROOM (1986) as the state of an individual regarding its attempts to fit the environment. It is expected that welfare improvements bring productivity gains, but to succeed in doing this it is essential to meet the animals'needs, in particular, in relation to their behavior (BROOM \& FRASER, 2010). The authors defined need as "a deficiency in an animal that can only be remedied by obtaining a particular resource or responding to a particular environmental or bodily stimulus". As an extension of this, it is important that the animals are able to express their natural behaviors, while satisfying their behavior requirements (EFSA, 2005). When an animal has a certain behavioral need which it cannot meet, its welfare could be seriously harmed (BROOM $\&$ MOLENTO, 2004). This is particularly relevant in the case of commercial production of rabbits, which are usually kept in cages with little opportunity to interact with their environment.

Rabbits are animals that, in free life, live in complex social groups and exhibit intense exploratory activity (TROCINO \& XICCATO, 2006), characterized by the expression of behaviors such as sniffing, digging and gnawing objects found in the environment. In captivity there are several restrictions that harm the expression of these and other behaviors, resulting in frustration and health problems (VERGA et al., 2007). Under such situations, they can develop physiological and behavioral abnormalities, indicating that their welfare is impaired (BROOM, 1991). In the specific case of rabbits housed in cages, it is hardly possible for them to meet their behavioral needs, because they are species that is adapted to complex environments (BARROS, 2011). This can result in increased stress and the manifestation of abnormal behaviors, such as biting the cage bars and excessive body care (HANSEN \& BERTHELSEN, 2000), as well as, expression of stereotypes, such as frequent shaking head and moving around in repeated circuits (always in the same way) inside the cage. To avoid these problems, various types of environmental enrichment have been studied, while taking into account their productivity, behavior and animal welfare (PRINCZ et al, 2008; BARROS, 2011). Environmental enrichment is defined as any change in the captive animals' environment to improve their welfare (NEWBERRY, 1995). Enrichment allows the animal to express part of their behavioral repertoire, and also reduce the stress caused by the lack of space or poor environment that usually results in inactivity (JORDAN et al, 2006; BARROS, 2011). Most enrichment studies described physical changes in the rabbits' environment (VERGA et al., 2004; PRINCZ, 2008; SILOTO et al., 2009), but few studies have reported the availability of food enrichment, which can be an easy alternative to apply and with low cost (LIDFORS, 1997).

Therefore, the objective of the study was to evaluate the effect of environmental enrichment on time spent in the expression of abnormal behaviors, self-cleaning and inactivity for rabbits kept in conventional cages.

\section{MATERIALS AND METHODS}

This study was carried out at the rabbit facilities in the Faculdade de Ciências Agrárias e Veterinárias, Universidade Estadual Paulista (FCAV-UNESP), Jaboticabal-SP, Brazil. Seventeen multiparous New Zealand rabbits, with average age of two years, were used. They were housed individually in galvanized wire cages $(80 \mathrm{~cm}$ long, $60 \mathrm{~cm}$ wide and $45 \mathrm{~cm}$ high) each containing a feeder, nipple drinker and a wooden board (180 $\mathrm{cm}^{2}$ area) arranged on the surface of the cage floor.

Observations were carried out in two stages: before (ST1) and after (ST2) the environmental enrichment was offered. At each stage, observations were made during four periods, two in the morning (from $06 \mathrm{~h} 00 \mathrm{~min}$ to $09 \mathrm{~h} 30 \mathrm{~min}$ ) and two in the afternoon (from $15 \mathrm{~h} 00 \mathrm{~min}$ to $18 \mathrm{~h} 00 \mathrm{~min}$ ). These periods were selected after preliminary observations, which characterized the periods of greatest daytime activity of the rabbits. Familiarization of the rabbits with the observer's presence was made the day before starting data collection, by carrying out twelve hours preliminary data collection, with observations made every 2 minutes. It was assumed that the rabbits were habituated to the observers' presence when their presence did not interfere with the rabbits' activities.

Enrichment with feed was used by offering three different forage species simultaneously: sugar cane (Saccharum officinarum sp.), mulberry (Morus alba) and ramie (Boehmeria nivea); provided ad 
libitum during the observation periods (morning and afternoon) in ST2. Sugar cane was offered without the rind and in pieces, while mulberry and ramie were offered as branches with leaves. All the food items were offered on the cage floors.

Throughout the study period, two observers carried out the recordings randomly switching between the animals to be observed. Observations were carried out directly by using focal-animal and instantaneous (every two minutes sampling interval) sampling methods (MARTIN \& BATESON, 1993). The following behavioral categories were recorded: Inactivity (I), animal stays motionless, remaining in the standing posture (supported on all four foot and the rear part of the body not in contact with the cage floor or the wooden board), or sitting (with both forepaws extended, rear limbs flexed, and rear of body in contact with the floor of the cage or wooden board) or lying (with the ventral aspect of the body in full contact with the cage or wooden board) with eyes open or closed; self-cleaning (SC), the animal uses the tongue to lick any part of its' body or forepaws, it could include raising the forepaws toward the mouth, licking them, and then passing them on the head, ears or near the eye region, and it also included the action of passing the forepaws along any part of its body; abnormal behaviors (AB): (a) the animal kept the mouth open in contact with any structure of the facility showing chewing movements, or (b) presented frequent movement with the head in the longitudinal axis, from side to side, or (c) passed the tongue on any structure of the installation; concentrate ingestion (CI): when the animal, with its head inside the feeder, apprehends, chews and swallows the concentrate; forage ingestion (FI): when the animal apprehends, chews and swallows the forage offered; and other activities (OA): encompassing the following activities: walking, drinking water, smelling the cage structures, digging, or interacting with the neighboring rabbits.

The times spent in each behavior were recorded during both stages, before (ST1) and after (ST2) adding the feed enrichment, and during both periods of the day (morning and afternoon). The means of I, SC, AB, CI and OA in ST1 and ST2 were compared by using the Wilcoxon test, with $95 \%$ minimum confidence interval. Statistical analyses were carried out using the SAS Statistical Package (Version 9.0, SAS Institute Inc. Cary NC).

\section{RESULTS}

Offering forage as an environmental enrichment reduced significantly the time that the rabbits spent eating concentrate, and the time spent on abnormal and self-cleaning behaviors in the morning $(\mathrm{P}<0.05)$ as well as inactivity in the afternoon $(\mathrm{P}<0.05)$, as shown in table 1 . The average time the rabbits spent eating forage were 51.58 and $14.23 \mathrm{~min}$ in the morning and afternoon, respectively.

During both stages (ST1 and ST2), the rabbits were more active in the morning, remaining inactive $35.17 \%$ of the observation time in this period, while in the afternoon the inactivity occurred for $85.06 \%$ of the observation time. Offering the environmental enrichment reduced inactivity in the afternoon $(9.29 \%, \mathrm{P}<0.05)$ and in the morning $(7.56 \%)$, but in this case the difference was not statistically significant $(\mathrm{P}>0.05)$.

The time spent by the rabbits presenting abnormal behaviors was affected by the environmental enrichment only in the morning, reducing it about three times (from 9.6 to $3.3 \%$ of the time spent in these activities). Although, no significant difference was observed in the afternoon for this variable, there was a reduction of 3.7 times in $\mathrm{AB}$ presentation (from 0.81 to $0.22 \%$ ), proportionately similar to the reduction observed in the morning.

Environmental enrichment also led to a reduction $(\mathrm{P}<0.05)$ in the expression of self-cleaning behavior in the morning, being $27.33 \%$ less relative to the time spent in this category during ST1. Conversely, environmental enrichment resulted in an increase in the time spent in SC in the afternoon period (43\%), although this was not statistically significant.

Similarly, the environmental enrichment also affected concentrate ingestion in the morning, reducing

Table 1 - Average time (min.) spend on each behavioral category before (ST1) and after (ST2) the use of environmental enrichment according to the evaluation periods (morning and afternoon).

\begin{tabular}{|c|c|c|c|}
\hline Behavioral Categories (min) & ST1 & ST2 & $\mathrm{Z}$ \\
\hline Inactivity (I) & $76.76^{\mathrm{a}}$ & $70.94^{\mathrm{a}}$ & 0.75 \\
\hline Self-cleaning (SC) & $48.00^{\mathrm{a}}$ & $34.88^{\mathrm{b}}$ & 2.11 \\
\hline Concentrate ingestion (CI) & $16.05^{\mathrm{a}}$ & $6.76^{\mathrm{b}}$ & 3.13 \\
\hline Abnormal Behaviors (AB) & $20.23^{\mathrm{a}}$ & $7.00^{\mathrm{b}}$ & 2.31 \\
\hline Other activities (OA) & $50.94^{\mathrm{a}}$ & $40.82^{\mathrm{a}}$ & 1.22 \\
\hline Inactivity (I) & $160.76^{\mathrm{a}}$ & $145.82^{b}$ & 3.10 \\
\hline Self-cleaning (SC) & $5.47^{\mathrm{a}}$ & $7.82^{\mathrm{a}}$ & -1.74 \\
\hline Concentrate ingestion (CI) & $4.17^{\mathrm{a}}$ & $2.11^{\mathrm{a}}$ & 1.76 \\
\hline Abnormal Behaviors (AB) & $1.47^{\mathrm{a}}$ & $0.41^{\mathrm{a}}$ & 0.79 \\
\hline Other activities (OA) & $10.11^{\mathrm{a}}$ & $11.58^{\mathrm{a}}$ & -0.10 \\
\hline
\end{tabular}

"Means followed by different letters, in the same row, are statistically different $(\mathrm{P}<0.05)$, by Wilcoxon test.

Ciência Rural, v.46, n.6, jun, 2016. 
the time spent on this activity by $58 \%$. Although there was no significant difference in $\mathrm{CI}$ during afternoon, there was also a reduction in the expression of this category, from 2.32 to $1.72 \%$ of the time.

\section{DISCUSSION}

The use of green forage as a source of food for rabbits is important (BOURNE, 2012; CLAUSS, 2012) since they are herbivorous animals with teeth and gastrointestinal system adapted to diets rich in fiber (BOURNE, 2012). When forage was supplied for rabbits kept in cages it reduced their inactivity and the expression of abnormal behaviors, selfcleaning and concentrate ingestion, but these changes depended on the day period (morning or afternoon).

The reduction in time the rabbits were inactive can be partly explained by forage consumption behavior replacing the inactivity behavior. Our results corroborated those reported by LIDFORS (1997), who observed that rabbits with access to alimentary environmental enrichment spent more time eating and interacting with the fodder, with consequent reduction in inactivity time. Similar results were also reported by PRINCZ et al. (2008) and VERGA et al. (2004), who observed an increase in exploratory behavior and a decrease in resting time (especially lying) when rabbits kept in cages were offered environmental enrichment. It is in the afternoon that rabbits spend most of their time inactive or dormant, and this was similar to what was reported in our study (GUNN \& MORTON, 1995; PRINCZ et al., 2008).

There was a substantial, 3-fold, reduction in the time spent on abnormal behaviors in both periods of the day, on offering the environmental enrichment. This result also corroborates those reported in previous studies in rabbits using other types of environmental enrichment, such as litter straw (SILOTO et al., 2009), wooden stick (VERGA et al., 2004), and hay and grass-cubes (LIDFORS, 1997); indicating that offering environmental enrichment for rabbits kept in cages can improve their welfare, as confirmed by reduction in the expression of abnormal behaviors.

Offering forage also results in a reduction in self-cleaning behavior in the morning period. According to LIDFORS (1997), who studied the effect of various types of enrichment on rabbit behavior, the animals receiving hay cubes made of grass showed less licking compared to those which were kept in enriched cages (with a box) and those which did not receive any enrichment (control); this result indicated that the reduction in the expression of SC behavior was dependent of the type of environmental enrichment used.

Paradoxically, it was observed an increase in the time spent in $\mathrm{SC}$ in the afternoon on providing environmental enrichment (although not statistical significant). This can be partially explained by the reduction in time spent inactive due to greater interaction with the enriched environment. In studies with wild rabbits, GIBB (1993) noted that body care behavior occurs only during a short period of time, amounting to only $2 \%$ of time that animals are active. Body care, such as self-cleaning, usually occurs for short periods, and it can be classified as a displacement activity, probably caused by disturbance (GUNN \& MORTON, 1995) and, in these cases, it can be classified as a stereotypy because the animals do not perform it to promote body hygiene (HANSEN \& BERTHELSEN, 2000). Similar to our results, HANSEN \& BERTHELSEN (2000) reported that rabbits kept in enriched cages spent an important part of their time on body hygiene, which could indicate, that even in enriched cages, there was a lack of environmental stimuli or, as described by GUNN \& MORTON (1995), a socially deprived state.

The decrease in concentrate ingestion can be explained by the replacement of this activity with forage ingestion. Hypothetically, this could lead to a nutritional imbalance or, alternatively, the rabbits could compensate for the reduced concentrate ingestion during the day, by increasing their intake at night; however, it would be necessary to conduct further studies to test this hypothesis.

The availability of forage as an alimentary environmental enrichment was shown to be a viable alternative for improving animal welfare, as it allowed the rabbits to meet part of their innate behavioral needs, through the expression of foraging. Improvement of animal welfare, through enriching the environment of conventional rabbit production, promotes the public image of intensive farming systems (JORDAN et al., 2006) and helps meet the new challenges of the consumer market.

\section{CONCLUSION}

Offering forage as an environmental enrichment for rabbits kept in cages decreased abnormal and self-cleaning behaviors, and reduced the animals' inactivity time. On this basis, we conclude that providing forage helps satisfy the behavioral needs of rabbits and consequently improves their welfare. We recommend the 
development of further studies on the behavior and welfare of rabbits that include other measures such as productivity, physiological indicators and preference tests.

\section{ACKNOWLEDGMENTS}

We would like to thank the Professor Jeffrey F. Lui and the staff of the rabbit facilities from Faculdade de Ciências Agrárias e Veterinária (FCAV), Universidade Estadual Paulista (UNESP), Jaboticabal-SP, Brazil for allowing us to carry out the study. We also thank Taciana Diesel and Paola Rueda for their assistance during the development of this study. Finally we express our gratitude to Professor Neville Gregory for comments and writing revision that greatly improved the manuscript.

\section{BIOETHICS \\ AND COMMITTEE APPROVAL}

\section{BIOSSECURITY}

This study was approved by the Comissão de Ética no Uso de Animais (CEUA) of the Faculdade de Ciências Agrárias e Veterinária (FCAV), Universidade Estadual Paulista (UNESP), Jaboticabal-SP, Brazil, at the meeting on $13^{\text {th }}$ March 2013, protocol number 004489/13.

\section{REFERENCES}

BARROS, T.F.M. Desempenho e comportamento de coelhos em crescimento em gaiolas enriquecidas. 2011. 66f. Dissertação (Mestrado em Zootecnia), Programa de Pós-graduação em Zootecnia, Universidade Estadual Paulista, Faculdade de Medicina Veterinária e Zootecnia, Botucatu, SP. Available from: $<$ http://hdl. handle.net/11449/96622>. Accessed: Mar. 20, 2015.

BOURNE, D. Hay for a healthy rabbit: the importance of appropriate feed. Veterinary Nurse, v.3, p.154-162, 2012. Available from: $<$ http://www.theveterinarynurse.com/cgi-bin/go.pl/library/article. cgi?uid=91299; article=33_3_154_162>. Accessed: Mar. 20, 2015. doi: $10.12968 /$ vetn.2012.3.3.154.

BROOM, D.M. Indicators of poor welfare. British Veterinary Journal, v.142, p.524-526, 1986. Available from: <http://endcap. eu/wp-content/uploads/2015/06/Broom-1986-Indicators-of-pooranimal-welfare.pdf>. Accessed: Sept. 15, 2015. doi: 10.1016/0001935(86)90109-0.

BROOM, D.M. Animal welfare: concepts and measurements. Journal of Animal Science, v.69, p.4167-4175, 1991. Available from: <https://www.animalsciencepublications.org/ publications/jas/pdfs/69/10/4167>. Accessed: Mar. 19, 2015. doi: 1991.69104167x.

BROOM, D.M.; MOLENTO, C.F.M. Animal welfare: concept and related issues - Review. Archives of Veterinary Science, v.9, n.2, p.1-11, 2004. Available from: <http://ojs.c3sl.ufpr.br/ojs2/index. php/veterinary/article/view/4057/3287>. Accessed: Mar. 19, 2015. doi: 10.5380/avs.v9i2.4057.

BROOM, D.M.; FRASER, A.F. Comportamento e bem estar de animais domésticos. 4. ed. Barueri: Manole, 2010. 452p.

CLAUSS, M. Clinical technique: feeding hay to rabbits and rodents. Journal of Exotic Pet Medicine, v.21, p.80-86, 2012.
Available from: <http://www.rabbit.org/care/Hay.pdf $>$. Accessed: Mar. 20, 2015. doi: 10.1053/j.jepm.2011.11.005.

EUROPEAN FOOD AND SAFETY AUTHORITY (EFSA). The impact of the current housing and husbandry systems on the health and welfare of farmed domestic rabbits. EFSA Journal, v.267, p.1-31, 2005. Accessed: Mar. 19, 2015. Available from: <http:// www.efsa.europa.eu/sites/default/files/scientific_output/files/ main_documents/267.pdf $>$.

GIBB, J.A. Sociality, time and space in a sparse population of rabbits (Oryctolagus cuniculus). Journal of Zoology, v.229, p.581-607, 1993. Available from: <http://onlinelibrary.wiley.com/ doi/10.1111/j.1469-7998.1993.tb02658.x/epdf >. Accessed: Mar. 20, 2015. doi: 10.1111/j.1469-7998.1993.tb02658.x.

GUNN, D.; MORTON, D.B. Inventory of the behaviour of New Zealandwhiterabbitsinlaboratorycages.AppliedAnimalBehaviour Science, v.45, p.277-292, 1995. Available from: <http://ac.els-cdn. com/0168159195006275/1-s2.0-0168159195006275-main.pdf? tid=71 ebdaf4-9de9-11e5-bcaa-00000aacb362\&acdnat=1449606346 c414302eca2779e96e103854da5b7061>. Accessed: Mar. 20, 2015. doi: 10.1016/0168-1591(95)00627-5.

HANSEN, L.T.; BERTHELSEN, H. The effect of environmental enrichment on the behavior of caged rabbits (Oryctolagus cuniculus). Applied Animal Behaviour Science, v.68, p.163-178, 2000. Available from: $<$ http://www.appliedanimalbehaviour.com/ article/S0168-1591(00)00093-9/pdf>. Accessed: Mar. 19, 2015. doi:10.1016/S0168-1591(00)00093-9.

JORDAN, D. et al. Environmental enrichment in growing rabbits. In: MAERTENS, L.; COUDERT, P. (Eds.) Recent advances in rabbit sciences. Melle: ILVO, 2006.p.113-120. Available from: $<$ http://world-rabbit-science.com/Documents/Cost848.pdf $>$. Accessed: Mar. 20, 2015.

LIDFORS, L. Behavioural effects of environmental enrichment for individually caged rabbits. Applied Animal Behaviour Science, v.52, p.157-169, 1997. Available from: <http://ac.els-cdn.com/ S0168159196011410/1-s2.0-S0168159196011410-main.pdf? tid $=1086934 \mathrm{c}-9 \mathrm{deb}-11 \mathrm{e} 5-\mathrm{ae} 12-00000 \mathrm{aacb} 35 \mathrm{e} \& \mathrm{acdnat}=144960 \overline{7}$ 042 92c0b1e616206f8ce1817324ad7dd3ad $>$. Accessed: Mar. 19, 2015. doi: 10.1016/S0168-1591(96)01141-0.

MARTIN, P.; BATESON, P. Measuring behaviour: an introductory guide. Cambridge: Cambridge University, 1993. 222p.

NEWBERRY, R.C. Environmental enrichment: Increasing the biological relevance of captive environments. Applied Animal Behaviour Science, v.44, p.229-243, 1995. Available from: $<$ http://www.appliedanimalbehaviour.com/article/01681591(95)00616-Z/pdf>. Accessed: Mar. 19, 2015. doi: 10.1016/0168-1591(95)00616-Z.

OLIVEIRA, C.B. et al. Diferenciação por qualidade da carne bovina: a ótica do bem-estar animal. Ciência Rural, v.38, n.7, p.2092-2096, 2008. Available from: <http://www.scielo.br/scielo. php?script $=$ sci_arttext\&pid $=$ S0103-84782008000700049\&lng $=$ en $\& n r m=$ iso $>$. Accessed: Mar. 19, 2015. doi: 10.1590/S010384782008000700049 .

PRINCZ, Z. et al. Behaviour of growing rabbits under various housing conditions. Applied Animal Behaviour Science, v.111, p.342-356, 2008. Available from: <http://ac.els-cdn.com/ S0168159107001980/1-s2.0-S0168159107001980-main.pdf? 
tid=1459b244-9dee-11e5-8bdd-00000aab0f27\&acdnat $=1449608$ 337 19565f812cf60487a1f62bec1e24ea87>. Accessed: Mar. 19, 2015. doi: 10.1016/j.applanim.2007.06.013.

SILOTO, E.V. et al. Temperatura e enriquecimento ambiental sobre o bem-estar de coelhos em crescimento. Ciência Rural, v.39, n.2, p.528-533, 2009. Available from: <http://www.scielo.br/pdf/cr/ v39n2/a81cr461.pdf $>$. Accessed: Mar. 20, 2015. doi: 10.1590/ s0103-84782008005000081.

TROCINO, A.; XICCATO, G.Animal welfare in reared rabbits: a review with emphasis on housing systems. World Rabbit Science, v.14, p.77-93, 2006. Retrieved from: <http://wrs.webs.upv.es/files/ journals/vol14(2)-trocino.pdf>. Accessed: Mar. 19, 2015. doi: $10.4995 /$ wrs. 2006.553
VERGA, M. et al. Effect of housing and environmental enrichment on performance and behaviour in fattening rabbits, Puebla, México, 2004. In: WORLD RABBIT CONGRESS, 8., 2004, Puebla, México. Proceedings... Puebla: World Rabbit Congress, 2004. 1516 p., p. 1283-1288. Available from: <http://world-rabbit-science.com/ WRSA-Proceedings/Congress-2004-Puebla/Papers/Welfare $\% 20$ \&\%20Ethology/W-Verga.pdf>. Accessed: Mar. 19, 2015.

VERGA, M. et al. Effects of husbandry and management systems on physiology and behaviour of farmed and laboratory rabbits. Hormones and Behaviour, v.52, p.122-129, 2007. Available from: $<\mathrm{http} / /$ ac.elscdn.com/S0018506X07000700/1-s2.0-S0018506X07000700-main. pdf? tid=9f93b0d8-9df0-11e5-8dcc-00000aab0f27\&acdnat $=14496$ 09430_4b2f88b200d1bfd237b08df378de7d69>. Accessed: Mar. 19, 2015. doi: 10.1016/j.yhbeh.2007.03.024. 